\title{
PENDAMPINGAN GURU DALAM PEMBELAJARAN "ASPEK NILAI MORAL AGAMA MELALUI PENDIDIKAN KARAKTER DAN PENGENALAN PANCASILA" DI PAUD LABSCHOOL JEMBER TAHUN PELAJARAN 2016-2017
}

\author{
Eky Prasetya Pertiwi \\ Fakultas Ilmu Pendidikan Pendidikan Guru Anak Usia Dini \\ Ikip PGRI Jember Jl. Jawa No 10 Jember \\ e-mail: eky.prasetya.pertiwi@gmail.com
}

\begin{abstract}
This community service is aimed to early childhood teachers and early childhood. The method of implementation and activity in this service was doing direct meeting with teachers and children in TK PAUD Labschool Jember. The direct meetings meant here are giving an accompaniment to teachers directly, helping teachers to give some materials related to moral aspect and introduction of pancasila for early childhood. This activity also involved some college students who have duty to be a companion, help in overseeing childhood behavior, and directly involved in instilling character education and introduction of Pancasila. The conclusions of this activity are: $a$. the teachers of Lab school are very appreciative in this community service activity. It showed from the result that all the participants took apart all the activities with discipline, $b$. all students of early childhood also looked happy in this accompaniment and they wanted more time in this activity, c. The teachers of Lab school are very enthusiastic that it showed from the result of interview which they wanted to do this accompaniment activity regularly.
\end{abstract}

Key words: teacher assistance, character building, Pancasila, early childhood

\begin{abstract}
Abstrak
Pengabdian Masyarakat ini ditujukan untuk Guru PAUD serta Anak Usia Dini. Metode kegiatan dan metode penyampaian dalam pengabdian yang dimaksud disini adalah mengadakan pertemuan langsung dengan guru dan anak -anak di TK PAUD Labschool Jember. Pertemuan Langsung yang dimaksud adalah memberikan pendampingan pada guru secara langsung, membantu guru memberikan materi mengenai aspek moral dan pengenalan Pancasila pada anak usia dini. Kegiatan ini juga melibatkan beberapa mahasiswa yang memiliki tugas menjadi pendamping serta membantu dalam mengawasi perilaku anak serta terlibat langsung dalam upaya penanaman pendidikan karakter dan pengenalan pancasila. Hasil Kegiatan, dapat ditarik beberapa kesimpulan sebagai berikut: a. Guru PAUD Labschool Jember sangat apresiatif terhadap pelaksanaan kegiatan pengabdian kepada masyakarat ini. Buktinya, sebagaimana ditunjukkan hasil bahwa para khalayak sasaran mengikuti keseluruhan rangkaian kegiatan pengabdian masyarakat ini dengan penuh disiplin, $b$. Anak - anak PAUD Labschool Jember juga sangat apresiatif terhadap pendampingan menginginkan adanya penambahan waktu bersama pendamping guru pada saat melakukan aktivitas pendampingan, c. Guru PAUD Labschool Jember sangat antusiasme, sebagaimana buktinya ditunjukkan hasil wawancara yang dilakukan secara langsung dan menginginkan kegiatan pendampingan ini dilakukan rutin.
\end{abstract}

Kata Kunci : Pendampingan Guru, Pendidikan Karakter, Pancasila dan AUD

\section{PENDAHULUAN}

Undang Undang Sistem Pendidikan Nasional menyebutkan bahwa Pendidikan merupakan suatu usaha sadar dan terencana untuk mewujudkan suasana belajar dan proses pembelajaran agar peserta didik secara aktif mengembangkan potensi dirinya untuk memiliki spiritual keagamaan, pengendalian diri, kepribadian, kecerdasan akhlak mulia, serta keterampilan yang diperlukan dirinya, masyarakat, bangsa, dan negara. Salah satu upaya dalam mengembangkan potensi diri anak adalah dengan pendidikan karakter. 
Pendidikan Karakter untuk Anak Usia Dini adalah suatu upaya untuk menanamkan nilai - nilai kebaikan supaya dapat menjadi kebiasaan ketika kelak dewasa atau pada jenjang pendidikan selanjutnya. Pendidikan anak usia dini merupakan pendidikan yang paling mendasar dan menempati kedudukan sebagai golden age dan sangat strategis dalam pengembangan sumber daya manusia (Direktorat PAUD, 2005). Rentang anak usia dini dari lahir sampai usia enam tahun adalah usia kritis sekaligus dalam proses pendidikan dan dapat mempengaruhi proses serta hasil pendidikan seseorang selanjutnya artinya pada periode ini merupakan periode kondusif untuk menumbuh kembangkan berbagai kemampuan, kecerdasan, bakat, kemampuan fisik, kognitif, bahasa, sosio - emosional dan spiritual.

Masa golden age juga merupakan masa pembentukan dan penentu masa depan. Masa depan seorang anak tidak terlepas dari perkembangan dan pertumbuhan anak sejak lahir, dimana perkembangan dan pertumbuhan anak akan menjadi optimal jika mendapat rangsangan atau stimulus dari lingkungan sekitar anak.Karakter dasar yang dimiliki anak usia dini diantaranya kebaikan, suka meniru, suka bermain, dan rasa ingin tahu yang tinggi

Hasil studi Lawrence J. Schweinhart (1994) dalam Megawangi menunjuukan bahwa pengalaman anak- anak di masa TK dapat memberikan pengaruh positif terhadap perkembangan anak selanjutnya. Oleh karena itu US Departemen of Healt and Services (2001) telah membuat sebuah pernyataan bahwa "kematangan sosial emosi anak usia dini adalah penentu keberhasilan anak di sekolah lanjutannya", dan juga memberikan rekomendasi tentang kompetensi yang harus dipakai oleh anak-anak usia TK yang mencakup: Percaya Diri (Confidence), Rasa ingin tahu (curiosity), Motivasi, Kemampuan kontrol diri (Self - control), Kemampuan bekerja sama (Cooperation), Mudah bergaul dengan sesamanya, Mampu berkonsentrasi, Rasa empati, Kemampuan berkomunikasi.

Menurut Doni Koesoema (2012) ada delapan belas pesan karakter yang harus ditanamkan pada anak, diantaranya: religius, jujur, toleransi, disiplin, kerja keras, kreatif, mandiri, demokratis, rasa ingin tahu, semangat kebangsaan, cinta tanah air, menghargai prestasi, bersahabat/komunikatif, cinta damai, gemar membaca, peduli lingkungan, peduli sosial, dan tanggung jawab.

Beberapa aspek perkemabangan anak usia dini: 1. Aspek Perkembangan Kognitif, Aspek perkembangan yang menunjukkan tingkat pengetahuan, pengertian, dan keterampilan dalam berpikir, 2 . Aspek Perkembangan Fisik, merupakan perkembangan pengendalian gerakan jasmaniah melalui kegiatan pusat syaraf, urat syaraf dan otot terkoordinasi (Hurlock:1998), 3. Aspek Perkembangan Bahasa, merupakan perkembangan bahasa yang menurut Hart \& Risley (Morrow 1993) mengatakan umur 2 tahun, anak-anak memproduksi rata-rata dari 338 ucapan yang dapat dimengerti dalam setiap jam, 4. Membaca dan menulis merupakan bagian dari belajar bahasa. Untuk bisa membaca dan menulis, anak perlu mengenal beberapa kata dan beranjak memahami kalimat. Hal ini mengajarkan anak tentang bunyi bahasa, 5. Aspek Perkembangan sosio - Emosional. Masa anak-anak awal merupakan masa dimana perilaku sosial yang menurut Hurlock (1998:252) terlihat diantaranya: kerjasama, persaingan, kemuarahan hati, hasrat akan penerimaan sosial, simpati, empati, ketergantungan, sikap ramah, sikap tidak mementingkan diri sendiri, meniru, perilaku kelekatan, 6. Perkembangan Moral dan Agama, Pengertian perilaku moral secara umum adalah perilaku yang sesuai dengan standart moral dari kelompok sosial tertentu. Perilaku moral ini dikendaikan oleh konsep moral. Konsep moral terbentuk dari peraturan perilaku yang telah menjadi kebiasaan bagi anggota suatu budaya. Jika ada perilaku moral, maka identifikasikan perilaku tak bermoral dan amoral. Perilaku tak bermoral merupakan perilaku yang tidak sesuai dengan harapan sosial atau konsep moral yang diakui masyarakat. Sedangkan perilaku amoral/ non moral merupakan perilaku yang ditampilkan karena ketidak acuhan terhadap harapan kelompok sosial dan bisa saja terjadi karena hal tersebut belum memahami peraturan atau ketentuan moral yang ada dalam lingkungan tersebut (tidak sengaja dilakukan), 7. Perkembangan Kreativitas Anak, “ Kreativitas" merupakan salah satu aspek perkembangan yang harus digali dan diasah sejak usia dini. Setiap orang pada dasarnya memiliki bakat kreatif yang dimiliki. Bakat tersebut berbeda beda macamnya. Di tinjau dari segi pendidikan bakat kreatif dapat ditingkatkan untuk itu perlu dipupuk sejak dini. Bila bakat kreatif tersebut tidak dipupuk maka bakat tersebut tidak akan berkembang. Pada anak -anak, kreativitas difokuskan pada proses pembuatan gagasan- 
gagasan didalam suasana yang tidak evaluatif akan membantu anak-anak menghasilkan lebih banyak gagasan-gagasan atau bergerak ke langkah berikutnya, evaluasi diri.

Perkembangan nilai moral dan agama berhubungan dengan nilai-nilai yang ada pada Pancasila. Dalam kaitannya dengan nilai moral, pancasila sebagai identitas bangsa yang seharusnya menjadi simbol dari pribadi bangsa seharusnya memiliki peran penting sebagai upaya dalam menanamkan nilai moral anak. Indonesia bukan hanya milik islam saja, tetapi ada berbagai macam agama yang ada dalam nilai nilai sila dalam pancasila khususnya sila ke satu. Nilai - nilai lain yang ada didalam pancasila juga perlu untuk dikenalkan pada anak usia dini. Hal ini dimaksudkan agar anak memiliki pemahaman mengenai nilai ketuhanan, kemanusiaan, persatuan, kerakyatan dan keadilan.

Pemahaman nilai - nilai yang ada dalam pancasila memiliki makna yang baik kepada tata kehidupan berbangsa dan bernegara. Saling menghargai teman yang memiliki perbedaan agama, saling mengasihi, dan saling berbagai antara sesama yang membutuhkan.

\section{PERMASALAHAN}

Sehubungan dengan adanya upaya penanaman nilai dan moral pada anak - anak usia dini di TK PAUD Labschool Jember,maka kegiatan pengabdian masyarakat ini dilaksanakan. Untuk itu kegiatan pengabdian ini difokuskan untuk menjawab masalah- masalah sebagai berikut:

a. Pendidikan Karakter seperti apakah yang sudah ditanamkan di TK PAUD Labschool Jember?

b. Bagaimana Pendampingan guru yang dilakukan ketika menanamkan pendidikan karakter pada aspek nilai noral agama di TK PAUD Labschool Jember?

c. Bagaimana pendampingan guru yang dilakukan ketika mengenalkan pancasila pada AUD di TK PAUD Labschool Jember?

\section{METODE PELAKSANAAN}

Metode kegiatan dan metode penyampaian dalam pengabdian yang dimaksud disini adalah mengadakan pertemuan langsung dengan guru dan anak -anak di TK PAUD Labschool Jember. PertemuanLangsung yang dimaksud adalah memberikan pendampingan pada guru secara langsung, membantu guru memberikan materi mengenai aspek moral dan pengenalan Pancasila pada anak usia dini. Kegiatan ini juga melibatkan beberapa mahasiswa yang memiliki tugas untuk membantu dalam mengawasi perilaku anak serta terlibat langsung dalam upaya penanaman pendidikan karakter dan pengenalan pancasila.

Metode yang dilaksanakanmeliputi:

a. Membantu memberikan pendampingan pada guru TK dalam menanamkan pendidikan karakter pada pembelajaran aspek nilai moral agama dan pengenalan pancasila

b. Mengidentifikasimasalah yang terjadidi lingkungan TK PAUD LabschoolJember, khususnyamengenainilaidan moral anak.

c. Membantu memberikan pendampingan pada guru pada saat pengenalan mengenai pemahaman pancasila

Kegiatan kepada masyarakat ini dilaksanakan di Taman Kanak - Kanak PAUD Labsschool IKIP PGRI Jember. Kegiatan dilaksanakan selama satu tahun, dimulai tanggal 25 Juli 2016 setiap hari Senin atau selasa danmengambil beberapa hari yang telah dikondisikan terlebih dahulu. Rincian pelaksanaan kegiatan tersaji pada table di bawah ini.

\begin{tabular}{|l|l|c|}
\hline \multicolumn{1}{|c|}{$\begin{array}{c}\text { Waktu } \\
\text { Kegiatan }\end{array}$} & \multicolumn{1}{|c|}{ Deskripsi Kegiatan } & Waktu \\
\hline 25 Juli 2016 & Pengenalan sambil bermain & $10.00-10.30$ \\
\hline 1 Agustus 2016 & $\begin{array}{l}\text { Pengenalan disiplin pada pembelajaran } \\
\text { ekstra bahasa inggris untuk anak usia } \\
\text { dini. Misal : bagaimana anak } \\
\text { memperhatikan guru, mematuhi aturan }\end{array}$ & $10.00-10.30$ \\
\hline
\end{tabular}




\begin{tabular}{|c|c|c|}
\hline & $\begin{array}{l}\text { pembelajaran ekstra bahasa inggris, } \\
\text { tertib saat mengikuti pembelajaran }\end{array}$ & \\
\hline 15-08-2016 & $\begin{array}{l}\text { Megenalkan peraturan didalam kelas } \\
\text { pada proses pembelajaran pengenalan } \\
\text { bahasa inggris }\end{array}$ & $10.00-10.30$ \\
\hline $22-08-216$ & $\begin{array}{l}\text { Mengenalkan aturan dalam kelas dan } \\
\text { sekolah pada TK A dan TK B }\end{array}$ & $10.00-10.30$ \\
\hline 29-08-2016 & $\begin{array}{l}\text { Mengenalkan aturan dalan kelas dan } \\
\text { sekolah pada TK A }\end{array}$ & $10.00-10.30$ \\
\hline $5-09-2016$ & $\begin{array}{l}\text { Mengenalkan aturan kelas dan sekolah } \\
\text { pada TK B }\end{array}$ & $10.00-10.30$ \\
\hline 12-09-2016 & $\begin{array}{l}\text { Belajar tata tertib kelas sambil belajar } \\
\text { bahasa inggris }\end{array}$ & $10.00-10.30$ \\
\hline 19-09-2016 & $\begin{array}{l}\text { Belajar tata tertib kelas sambil belajar } \\
\text { bahasa inggris }\end{array}$ & $10.00-10.30$ \\
\hline 26-09-2016 & $\begin{array}{l}\text { Belajar menghargai perbedaan pendapat } \\
\text { melalui pengenalan buah dan sayur }\end{array}$ & $10.00-10.30$ \\
\hline $3-10-2016$ & $\begin{array}{l}\text { Belajar mengemukakan pendapat } \\
\text { melalui buah kesukaan }\end{array}$ & $10.00-10.30$ \\
\hline $10-10-2016$ & $\begin{array}{l}\text { Belajar menghargai perbedaan pendapat } \\
\text { melalui binatang kesukaan }\end{array}$ & $10.00-10.30$ \\
\hline $17-10-2016$ & $\begin{array}{l}\text { Belajar mengemukakan pendapat } \\
\text { melalui binatang kesukaan }\end{array}$ & $10.00-10.30$ \\
\hline $24-10-2016$ & Pengenalan aturan dalan kelas & $10.00-10.30$ \\
\hline $31-10-2016$ & Belajar mematuhi aturan dalam kelas & $10.00-10.30$ \\
\hline 14-11-2016 & $\begin{array}{l}\text { Belajar mendengarkan pendapat teman } \\
\text { sekelas }\end{array}$ & $10.00-10.30$ \\
\hline 22-11-2016 & $\begin{array}{l}\text { Mengunjungi masjid chengho, } \\
\text { memperkenalkan anak usia dini } \\
\text { mengenai nilai agama pada sila pertama } \\
\text { Pancasila }\end{array}$ & $10.00-10.30$ \\
\hline $7-12-2016$ & Pengenalan Pancasila & $10.00-10.30$ \\
\hline $12-12-2016$ & $\begin{array}{l}\text { Pemahaman mengenai nilai-nilai yang } \\
\text { terkandung dalam pancasila }\end{array}$ & $10.00-10.30$ \\
\hline $19-12-2016$ & $\begin{array}{l}\text { Pemahaman mengenai sila pertama, } \\
\text { pengenalan berbagai macam agama } \\
\text { yang ada di Indonesia }\end{array}$ & $10.00-10.30$ \\
\hline $26-12-2016$ & $\begin{array}{l}\text { Pemahaman mengenai sila kedua, } \\
\text { mengenai menghargai sesama, dan sikap } \\
\text { saling menyayangi sesama teman }\end{array}$ & $10.00-10.30$ \\
\hline 3-01-2017 & $\begin{array}{l}\text { Pemahaman mengenai sila ketiga, } \\
\text { mengenai persatuan . hidup rukun } \\
\text { sesama teman }\end{array}$ & $10.00-10.30$ \\
\hline $10-01-2017$ & $\begin{array}{l}\text { Pemahaman sila ke empat dan sila } \\
\text { kelima }\end{array}$ & $09.00-10.30$ \\
\hline $17-01-2017$ & $\begin{array}{l}\text { Pendalaman mengenai agama melalui } \\
\text { praktik shalat }\end{array}$ & $09.00-10.30$ \\
\hline 24-01-2017 & $\begin{array}{l}\text { Penanaman pendidikan karakter melalui } \\
\text { pembuatan bunga kertas }\end{array}$ & $09.00-10.30$ \\
\hline 31-01-2017 & $\begin{array}{l}\text { Penanaman karakter dengan komunikasi } \\
\text { melalui penggunaan Telpn }\end{array}$ & $09.00-10.30$ \\
\hline 6-02-20017 & $\begin{array}{l}\text { Melatih anak agar berani } \\
\text { mengemukakan pendapat }\end{array}$ & $10.00-10.30$ \\
\hline 13-02-2017 & Melatih anak untuk berani & $10.00-10.30$ \\
\hline
\end{tabular}




\begin{tabular}{|l|l|c|}
\hline & mengemukakan pendapat & \\
\hline $20-02-2017$ & $\begin{array}{l}\text { Melatih anak untuk berani tampil } \\
\text { didepan umum }\end{array}$ & $10.00-10.30$ \\
\hline $27-02-2017$ & $\begin{array}{l}\text { Melatih anak untuk berani tampil } \\
\text { didepan umum }\end{array}$ & $10.00-10.30$ \\
\hline $06-03-2017$ & $\begin{array}{l}\text { Bermain sambil belajar menghargai } \\
\text { pendapat teman }\end{array}$ & $10.00-10.30$ \\
\hline $14-03-2017$ & $\begin{array}{l}\text { Pengulangan mengenai pemahaman } \\
\text { nilai pada sila 1 dan 2 }\end{array}$ & $10.00-10.30$ \\
\hline $21-03-2017$ & $\begin{array}{l}\text { Pengulangan mengenai pemahaman } \\
\text { nilai pada sila 3 dan 4 }\end{array}$ & $10.00-10.30$ \\
\hline $28-03-2017$ & $\begin{array}{l}\text { Pengulangan mengenai pemahaman } \\
\text { nilai pada sila 5 }\end{array}$ & $09.00-10.30$ \\
\hline $6-04-2017$ & $\begin{array}{l}\text { Mengenalkan anak pada gambar - } \\
\text { gambar pancasila dengan cara mewarnai }\end{array}$ & $\begin{array}{l}\text { Memperkenalkan anak pada tata tertib } \\
\text { dijalan raya }\end{array}$ \\
\hline $10-04-2017$ & $\begin{array}{l}\text { Bermain kereta api sambil mengenalkan } \\
\text { pancasila }\end{array}$ & $09.00-10.30$ \\
\hline $17-04-2017$ & $\begin{array}{l}\text { Bermain kereta api sambil mengenalkan } \\
\text { pancasila }\end{array}$ & $09.00-10.30$ \\
\hline $24-04-2017$ & \multicolumn{2}{|l}{} \\
\hline
\end{tabular}

\section{LUARAN}

Tujuan kegiatan pengabdian kepada masyarakat ini pada dasarnya memiliki tujuan diantaranya:

1. Untuk mengetahui Pendidikan Karakter yang sudah ditanamkan di TK PAUD Labschool Jember

2. Untuk mengetahui Pendampingan guru yang dilakukan ketika menanamkan pendidikan karakter pada aspek nilai noral agama di TK PAUD Labschool Jember

3. Untuk mengetahui pendampingan guru yang dilakukan ketika mengenalkan pancasila pada AUD di TK PAUD LabschoolJember

Manfaat kegiatan pengabdian masyarakat ini adalah

a. Memberikan bantuan pada guru TK PAUD Labschool Jember dalam menanamkan pendidikan karakter pada anak - anak di TK tersebut berupa pendampingan.

b. Membantu guru memberikan pendampingan pada saat menanamkan pendidikan karakter pada aspek nilai noral agama di TK PAUD Labschool Jember.

c. Membantu memberikanpendampingan pada guru ketika mengenalkan pancasila dan nilainilai yang terkandung di tiap sila pada AUD di TK PAUD Labschool Jember

\section{HASIL}

Data hasil kegiatan pengabdian kepada masyarakat ini berupa data deskriptif yaitu data berupa gambaran secara tertulis dan dapat diamati. Data tersebut menggunakan metode observasi dan pengamatan, tujuannya untuk mengetahui manfaat dan efektivitas aspek proses yang diperoleh dari pendampingan guru TK di PAUD Labschool IKIP PGRI Jember. Pengamatan dilakukan pada guru dan anak untuk melihat sejauh mana penanaman pendidikan karakter di sekolah tersebut dilakukan. Data yang terlah diperoleh dianalisis dan disajikan dalam bentuk narasi.

Berdasarkanwawancara, tanyajawab dan pengamatan langsung selama kegiatan berlangsung, kegiatan pengabdian pada masyarakat ini memberikan hasil sebagai berikut: 


\section{Pendidikan Karakter yang sudah ditanamkan di TK PAUD Labschool Jember \\ Pembelajaran Pendidikan Karakter yang sudah ditanamkan di TK PAUD Labschool IKIP PGRI Jember diantaranya adalah pembelajaran berbasis kasih sayang, berbasis kebersamaan, berbasis ketauhidan, berbasis kemandirian, berbasis kreativitas, berbasis lingkungan \\ Pendampingan guru yang dilakukan pada saat menanamkan pendidikan karakter pada aspek nilai noral agama di TK PAUD Labschool IKIP PGRI Jember}

Pendampingan guru yang dilakukan pada saat menanamkan pendidikan karakter pada aspek nilai moral agama di TK PAUD Labschool Jember adalah membantu memberikan pengawasan pada anak - anak di TK PAUD Labschool pada saat menjalankan aktifitas belajar sehari - hari dan pada saat menjalankan kegiatan ibadah secara bersama-sama. Kegiatan - kegiatan tersebut diantaranya:

1. Membantu membetulkan gerakan shalat ketika salah

2. Membantu membetulkan beberapa doa yang diucapkan ketika salah

3. Membantu berkomunikasi aktif dengan anak - anak pada sat-saat diperlukan. Misalnya, memberikan pengertian mengenai benar-salah, baik dan buruk

\section{Pendampingan guru yang dilakukan ketika mengenalkan pancasila pada AUD di TK PAUD Labschool Jember}

Pendampingan guru yang dilakukan ketika mengenalkan pancasila pada AUD di TK PAUD Labschool IKIP PGRI Jember adalah dengan menggunakan metode:

1. Metode Bercerita

Menyampaikan nilai moral yang terkandung dalam pancasila pada anak usia dini bisa menggunakan boneka atau gambar pahlawan yang dipotong kemudian ibu guru bercerita secara langsung mengenai baik dan buruk secara jelas. Secara tidak langsung anak-anak dikenalkan dengan beberapa pahlawan yang ada di Indonesia.

2. Metode Bernyanyi

Metode bernyanyi adalah suatu pendekatan pembelajaran yang mampu membuat anak senang dan bergembira. Anak diajak untuk membangun kondisi psikis dengan jiwa yang bahagia dan mengembangkan rasa melalui unkapan dan nada. Metode bernyanyi akan membantu anak dalam mengenal nilai moral mengenai kebersamaan. Misalnya anak dikenalkan lagu Indonesia Raya pada waktu upacara bendera. Nilai moral yang terkandung didalam lagu kebangsaan akan secara sengaja membantu anak membangun jiwa kebangsaan sejak dini.

3. Metode Bermain

Dunia anak tidak akan jauh dari aktifitas bermain. Dengan bermain anak akan diajak bergembira dengan menggerakkan motorik kasar dan halus. Implementasi nilai moral pancasila pada anak usia dini dengan metode bermain dapat dicontohkan dengan bermain benteng-bentengan. Permainan tradisional namun mampu menumbuhkan jiwa bela negara. Permainan benteng-bentengan mengajak anak -anak untuk melindungi daerah kekuasaan" agar tidak dimasuki oleh orang lain.

Bermain dengan bermain peran juga bisa diajarkan pada anak usia dini. Misalnya saja guru di taman kanak-kanak menceritakan kisah pahlawan yang kemudian diperankan secara langsung oleh anak-anak. Atau guru bisa juga memutarkan film perjuangan singkat bangsa Indonesia yang kemudian diperagakan secara langsung oleh anak-anak.

4. Metode Pendidikan dan Pembiasaan dalam berperilaku

Anak usia dini merupakan anak-anak yang masih dalam tahap belajar. Selanjutnya anak anak akan belajar mengenai atauran-aturan yang ada disekitarnya. Memberikan peraturan mempunyai dua fungsi yang sangat penting dalam membantu anak menjadi makhluk bermoral. Pertama, peraturan mempunyai nilai pendidikan, sebab peraturan memperkenalkan pada anak perilaku yang disetujui anggota kelompok tersebut. 
Menurut Kohlberg (1964), pada tahap ini dinamakan sebagai tahap tingkat 1. Moralitas Prakonvensional. Pada tahap ini anak-anak berasumsi bahwa otoritas-otoritas yang penuh kuasa telah menurunkan seperangkat aturan baku yang harus mereka patuhi tanpa protes. Hal ini dalam pembelajaran di Taman Kanak-kanak bisa dilakukan ketika anak-anak bermain, bertamasya, atau berkunjung kesuatu tempat. Anak-anak diajarkan untuk mematuhi peraturan permainan yang mereka lakukan. Anak -anak juga diajarkan mengenal aturan tempat lain misalnya ketika anak-anak diajak bertamasya kekebun binatang. Anak-anak tidak boleh memasukkan tangan ke kandang hewan atau ketika anak-anak diajarkan menjenguk teman yang sakit. Dimana anak-anak akan belajar mematuhi aturan rumah sakit.

\section{Metode Diskusi}

Pada saat ini anak-anak lebih kritis dalam menanggapi aturan-atauran yang akan dipelajari, maka dalam hal ini akan memerlukan diskusi yang baik antara anak dan guru sebagai proses pembelajaran agar anak lebih bisa memahami mengapa aturan itu harus ditaati. karena perilaku anak terjadi secara tidak disengaja dan tidak direncanakan. Anak -anak mencoba suatu pola perilaku untuk melihat apakah itu memenuhi standart sosial dan memperoleh persetujuan sosial.

6. Metode identifikasi

Metode identifikasi digunakan anak-anak karena ada perasaan kagum kepada seseorang. Identifikasi sebagai sumber belajar perilaku moral semakin penting tatkala anak bertambah besar dan melawan terhadap disiplin di rumah dan di sekolah. Memiliki seseorang untuk identifikasi diri akan mengisi kesenjangan dan memberi pegangan yang diperlukan bagi perkembangan perilaku moral.

Metode identifikasi ini bisa dilakukan ketika ibu atau bapak guru pengajar ditaman kanak-kanak bercerita di kelas. Misalnya bercerita tentang "Menik yang tersesat di tempat wisata". Cerita yang menggambarkan anak-anak yang tidak mematuhi aturan yang adaketikasedangpergibertamasya.Contoh lain adalahcerita Raden Ajeng Kartini, seorangperempuan Indonesia yang tekundalambelajardsb.

Menurut Piaget (1932) ada tiga tahap perkembangan moral yang diikuti dengan ketentuan umur yaitu:

1. Tahap pra-moral, yaitu anak yang berumur dibawah 4 tahun

2. Tahap heteronomous, yaitu anak yang berumur antara 4-8 tahun

3. Tahap otonomous yaitu anak yang berumur 9-12 tahun

Tahap tahap perkembangan penalaran moral tidak dapat berbalik (irreverible) yaitu bahwa suatu tahapan yang telah dicapai seseorang tidak mungkin kembali mundur ketahapandibawahnya. (Kohlberg, 1964)

Penanaman pendidikan nilai dan moral pada Taman Kanak-kanak dimasukkan dalam Rencana Semester di Taman Kanak-kanak. Perencanaan semester tersebut diantaranya:

(a). nilai-nilai agama dan moral, (b). Perkembangan Fisik yang menyangkut motorik kasar, motorik halus, dan kesehatan fisik, (c). Perkembangan Kognitif, menyangkut pengetahuan umum dan sains, konsep bentuk warna, ukuran dan pola, konsep bilangan lambang dan bilangan huruf, (d). Perkembangan Bahasa, menyangkut menerima bahasa, mengungkapkan bahasa dan keaksaraan, (e). Sosial Emosional

Pemberian pendidikan nilai moral pancasila pada anak usia dini pada umumnya masuk dalam lingkup pengembangan nilai-nilai agama dan moral dengan capaian pembelajaran misal, anak mampu mengenal Tuhannya, menirukan gerakan ibadah, mengucapkan doa serta berperilaku baik. Seperti yang telah dibahas sebelumnya bahwa pendidikan moral membantu anak mengerti dan memahami mengenai baik-buruk, benar-salah dan membantu mengambil keputusan.

Pendidikan nilai moral pancasila pada anak usia dini di TK sebaiknya tidak hanya dimasukkan pada lingkup perkembangan nilai-nilai agama dan moral saja tetapi juga semua aspek perkembangan. 
Tabel: 1. Gambaran hasil lingkup perkembangan yang dipelajari anak usia dini di TK:

\begin{tabular}{|c|c|c|c|}
\hline Lingkup Perkembangan & $\begin{array}{l}\text { Capaian } \\
\text { Perkembangan }\end{array}$ & $\begin{array}{l}\text { Tingkat Pencapaian } \\
\text { Perkembangan }\end{array}$ & Indikator \\
\hline $\begin{array}{l}\text { Nilai-nilai agama dan } \\
\text { moral }\end{array}$ & $\begin{array}{l}\text { Anak mampu } \\
\text { mengenal Tuhan } \\
\text { dalam masing } \\
\text { masing kepercayaan }\end{array}$ & $\begin{array}{l}\text { Misal: mengenal } \\
\text { beragam agama } \\
\text { yang ada di negara } \\
\text { Indonesia, } \\
\text { membiasakan diri } \\
\text { beribadah, } \\
\text { memahami perilaku } \\
\text { mulia }\end{array}$ & $\begin{array}{ll}\text { - } & \text { Menyebutkan } \\
\text { nama- nama } \\
\text { agama di } \\
\text { Indonesia } \\
\text { - } \\
\text { Menyebutkan } \\
\text { kitab suci } \\
\text { masing-masing } \\
\text { agama yang ada } \\
\text { di negara } \\
\text { Indonesia } \\
\text { - Bertindak } \\
\text { sopan,jujur, suka } \\
\text { menolong, } \\
\text { menghormati } \\
\text { orang lain } \\
\text { Menghormti } \\
\text { agama orang lain }\end{array}$ \\
\hline Perkembangan Fisik & $\begin{array}{l}\text { Anak mampu } \\
\text { melakukan aktifitas } \\
\text { fisik serta } \\
\text { berkreatifitas } \\
\text { mengembangkan } \\
\text { gagasan }\end{array}$ & $\begin{array}{l}\text { Misal: melakukan } \\
\text { gerakan tubuh } \\
\text { dengan berolah } \\
\text { raga, senam fantasi } \\
\text { (bentuk meniru), } \\
\text { melipat kertas, } \\
\text { memiliki } \\
\text { kesesuaian antara } \\
\text { tinggi badan, berat } \\
\text { badan dan usia, dsb }\end{array}$ & $\begin{array}{ll}\text { Berlari dan } \\
\text { melompat } \\
\text { - } & \text { Memanjat, } \\
\text { bergantung dan } \\
\text { berayun } \\
\text { - } & \text { Menggambar } \\
\text { bebas mengenai } \\
\text { berbagai macam } \\
\text { kekayaan } \\
\text { indonesia } \\
\text { Menggunting } \\
\text { berbagai macam } \\
\text { gambar pakaian } \\
\text { adat atau pulau } \\
\text { di Indonesia }\end{array}$ \\
\hline Perkembanagn Kognitif & $\begin{array}{l}\text { Anak mampu } \\
\text { mengenal konsep } \\
\text { sains sederhana } \\
\text { didalam kehidupan } \\
\text { sehari-hari, bentuk, } \\
\text { warna, ukuran dan } \\
\text { keaksaraan }\end{array}$ & $\begin{array}{l}\text { Misal:Mengenal } \\
\text { benda berdasarkan } \\
\text { fungsi }\end{array}$ & $\begin{array}{ll}\text { - } & \text { Menyebutkan } \\
\text { nama- nama } \\
\text { benda dan fungsi } \\
\text { - Menyebutkan } \\
\text { sebab akibat } \\
\text { terjadiny polusi } \\
\text { dan dampaknya } \\
\text { bagi lingkungan }\end{array}$ \\
\hline Perkembangan Bahasa & $\begin{array}{l}\text { Anak mampu } \\
\text { berkomunikasi } \\
\text { secara efektif } \\
\text { dengan lisan dan } \\
\text { memiliki } \\
\text { kebendahaaraan } \\
\text { kata }\end{array}$ & $\begin{array}{l}\text { Misal : memahami } \\
\text { aturan dalam suatu } \\
\text { permainan, } \\
\text { mengerti beberapa } \\
\text { perintah secara } \\
\text { bersamaan }\end{array}$ & $\begin{array}{ll}\text { - } & \text { Menjawab } \\
\text { pertanyaan } \\
\text { dengan kalimat } \\
\text { yang tepat } \\
\text { Mentataati } \\
\text { peraturan } \\
\text { permainan } \\
\text { (sebagai salah } \\
\text { satu upaya } \\
\text { peningkatan } \\
\text { kedisiplinan) }\end{array}$ \\
\hline
\end{tabular}




\begin{tabular}{|c|c|c|c|}
\hline $\begin{array}{l}\text { Perkembangan Sosial } \\
\text { Emosi }\end{array}$ & $\begin{array}{l}\text { Anak mampu } \\
\text { mandiri, mengikuti } \\
\text { aturan serta dapat } \\
\text { mengandalkan } \\
\text { emosi }\end{array}$ & $\begin{array}{l}\text { Misal : } \\
\text { menunjukkan sikap } \\
\text { toleran, } \\
\text { mnunjukkan sikap } \\
\text { kooperatif, } \\
\text { mengenal tata } \\
\text { krama, sopan } \\
\text { santun, niulai } \\
\text { budaya masyarakat } \\
\text { setempat, } \\
\text { memahami aturan, } \\
\text { disiplin, } \\
\text { menunjukkan rasa } \\
\text { empati, } \\
\text { menunjukkan sikap } \\
\text { gigih dan tidak } \\
\text { mudah menyerah, } \\
\text { bangga terhadap } \\
\text { hasil karya sendiri, } \\
\text { menghargai } \\
\text { keunggulan orang } \\
\text { lain. Dsb }\end{array}$ & $\begin{array}{ll}\text { - } & \text { Mau berbagi } \\
\text { dengan teman } \\
\text { - } & \text { Senang } \\
\text { menolong } \\
\text { - } & \text { Mau menunggu } \\
\text { giliran } & \text { Mengajak teman } \\
\text { - } & \text { bermain } \\
\text { - } & \text { Menunjukkan } \\
\text { emosi yang } \\
\text { wajar, senang, } \\
\text { sedih, antusias, } \\
\text { dsb } \\
\text { Berbahasa sopan } \\
\text { dan bermuka } \\
\text { manis } \\
\text { Bertingkah laku } \\
\text { sopan dan santun } \\
\text { Mengucap } \\
\text { terimakasih } \\
\text { Mentaati } \\
\text { peraturan } \\
\text { Menyelesaikan } \\
\text { tugas sendiri } \\
\text { Menunjukkan } \\
\text { rasa empati dsb }\end{array}$ \\
\hline
\end{tabular}

Sumber : Tim Guru TK PAUD LABSCHOOL Jember 2016

Tabel tersebut di atas adalah gambaran mengenai hasil lingkup perkembangan yang dipelajari anak usia dini di Taman Kanak- kanak. Lingkup Perkembangan yang ada pada usia taman kanak-kanak diantaranya nilai-nilai agama dan moral, perkembangan fisik, perkembangan kognitif, perkembangan bahasa, serta perkembangan sosial emosi. Adapun capaian perkembangan pada lingkup perkembangan nilai nilai agama dan moral adalah anak mampu mengenal Tuhan dalam masing-masing kepercayaan. Tingkat pencapaian perkembangan anak misalnya mengenal beragam agama yang ada di negara Indonesia, membiasakan diri beribadah, memahami perilaku mulia. Indikatornya adalah menyebutkan nama-nama agama di Indonesia, menyebutkan kitab suci masing - masing agama yang ada di negara Indonesia,bertindak sopan, jujur, suka menolong, menghormati orang lain serta menghormati agama orang lain.

Lingkup perkembangan fisik, capaian perkembangan misalnya anak mampu melakukan aktifitas fisik serta berkreatifitas mengembangkan gagasan. Tingkat pencapaian perkembangannya adalah melakukan gerakan tubuh dengan berolah raga, senam fantasi (bentuk meniru), melipat kertas, memiliki kesesuaian antara tinggi badan, berat badan dan usia. Indikatornya: berlari dan melompat, memanjat, bergantung dan berayun, menggambar bebas mengenai berbagai macam kekayaan Indonesia, menggunting berbagai macam gambar pakaian adat, atau pulau di Indonesia.

Lingkup perkembangan Kognitif, capaian perkembangannya, anak mampu mengenal konsep sains sederhana didalam kehidupan sehari-hari, bentuk warna, ukuran dan keaksaraan. Tingkat capaian perkembangannya misalnya mengenal benda berdasarkan fungsi. Sedangkan indikatornya adalah menyebutkan nama-nama benda dan fungsi, menyebutkan sebab akibat terjadinya polusi dan dampaknya bagi lingkungan.

Lingkup perkembangan bahasa, capaiannya dalah anak mampu berkomunikasi secara efektif dengan lisan dan memiliki kebendaharaan kata. Tingkat capaian 
perkembangannya misalnya memahami aturan dalam suatu permainan, mengerti beberapa perintah secara bersamaan. Indikatornya diantaranya mentaati peraturan permainan (Sebagai salah satu upaya peningkatan kedisiplinan).

Lingkup perkembangan Sosial emosi, capaiannya adalah anak mampu mandiri, mengikuti aturan serta dapat mengandalkan emosi. Tingkat capaian perkembangan diantaranya menunjukkan sikap kooperatif, mengenal tata krama, sopan santun, nilai budaya masyarakat setempat, memahami aturan, disiplin, menunjukkan sikap gigih dan tidak mudah menyerah, bangga terhadap hasil karya sendiri, menghargai keunggulan orang lain dan sebagainya. Sedangkan untuk indikatornya diantaranya : mau berbagi dengan teman, senang menolong, mau menunggu giliran, mengajak teman bermain, menunjukkan emosi yang wajar (Senang, sedih, antusias, dsb), berbahasa sopan dan bermuka manis, bertingkah laku sopan dan santun, mengucap terimakasih, mentaati peraturan, menyelesaikan tugas sendiri, menunjukkan rasa empati dan sebagainya.

Dari lingkup perkembangan anak usia dini, nilai agama nilai moral pancasila ada dalam setiap lingkup perkembangannya. Pada sila pertama yang berbunyi ketuhanan yang maha Esa ada pada aspek perkembangan agama dan nilai moral anak. Contohnya belajar mengenal ajaran agama yang ada di Indonesia, menjalankan ibadah sesuai agama dan kepercayaannya. Sila kedua adalah kemanusiaan yang adil dan beradap berada aspek perkembangan sosial emosi anak. Misalnya, mengenal tata krama, sopan, menunjukkan rasa empati. Sila ke tiga yaitu persatuan Indonesia, berada bada aspek berkembangan fisik dan bahasa. Misalnya mengikuti olah raga dan upacara di sekolah. Sila keempat, kerakyatan yang di pimpin oleh hikmat kebijaksanaan dalam permusyawaratan perwakilan berada pada aspek perkembangan kognitif dan sosial emosi. Misalnya anak diperkenalkan dengan pos kamling dilingkungan sekitar dan dijelaskan manfaatnya, anak diajak mematuhi aturan disekolah, dsb. Sila kelima, keadilan bagi seluruh rakyat Indonesia bisa dimasukkan pada lingkup perkembangan nilai agama dan moral. Misalnya anak diajak berkeliling sawah di daerah pedesaan, anak diajak bagaimana berempati dan saling berbagi. Anak di ajak untuk berbagi kebahagiaan dengan sesama

\section{KESIMPULAN}

Berdasarkan analisis data-data deskriptif hasil kegiatan pengabdian kepada masyarakat sebagaimana hasil Kegiatan, dapat ditarik beberapa kesimpulan sebagai berikut:

a. Guru PAUD Labschool Jember sangat apresiatif terhadap pelaksanaan kegiatan pengabdian kepada masyakarat ini. Buktinya, sebagaimana ditunjukkan hasil bahwa para khalayak sasaran mengikuti keseluruhan rangkaian kegiatan pengabdian masyarakat ini dengan penuh disiplin

b. Anak - anak PAUD Labschool Jember juga sangat apresiatif terhadap pendampingan menginginkan adanya penambahan waktu bersama pendamping guru pada saat melakukan aktivitas pendampingan.

c. Guru PAUD Labschool Jember sangat antusiasme, sebagaimana buktinya ditunjukkan hasil wawancara langsung:

1. Guru mengaku sangat puas dengan adanya pendampingan yang dilakukan oleh Dosen IKIP PGRI Jember, karena membantu keseluruhan rangkaian kegiatan pembelajaran khususnya aspek Nilai dan Moral agama;

2. Setelah mengikuti keseluruhan rangkaian kegiatan pengabdian kepada masyarakat ini, ada perubahan mengenai metode pembelajaran dalam menanamkan pendidikan karakter.

3. Sebagian besar khalayak sasaran baik guru dan anak-anak mengaku sekarang ini mereka menjadi lebih mengerti mengenai Pancasila;

4. Sebagian besar khalayak sasaran (guru dan anak-anak) mengaku sekarang ini mereka juga merasa lebih memahami penting dengan adanya pendampingan guru guna menambah wawasan dalam pembelajaran aspek nilai dan moral dalam 
uapaya penanaman pendidikan karakater danpemahaman mengenai pengenalan Pancasila pada anak usia dini;

\section{SARAN}

Saran-saran yang dapat diajukan berkaitan dengan kegiatan Pengabdian kepada masyarakat yang dilaksanakan di TK PAUD Labschool Jember adalah sebagai berikut:

a. Para guru TK PAUD Labschool Jember berharap adanya perhatian lebih dari para akademisi khususnya mengenai penanaman pendidikan karakter pada anak usia dini.

b. Perlunya adanya pantauan yang intens terhadap anak- anak khususnya yang memiliki masalah dengan nilai dan moral. Untuk itu diharapkan adanya kerjasama antara orang tua, guru dan dosen untuk menganalisis masalah nilai dan moral yang dihadapi anak - anak sejak usia dini. Kemudian diharapkan menemukan solusi yang baik untuk pembentukan kepribadian anak ke arah yang lebih baik melalui pendidikan karakter.

c. Keseimbangan antara jumlah guru dan anak didik dalam proses pembelajaran di TK perlu diperhatikan, karena anak-anak butuh pengawasan ekstra serta komunikasi yang berulangulang saat mereka beraktifitas.

d. Memberikan kesempatan dan waktu tersendiri pada penanaman pendidikan pancasila sejak usia dini di sekolah TK.

e. Melalui Pendampingan guru ini diharapkan akan ada peningkatan dan perubahan mutumengenai kualitas nilai dan moral dan pengenalan lebih dalam mengenai pancasila oleh anak sejak usia dini.

\section{DAFTAR PUSTAKA}

[1] Chourmain I. 2011. Pendekatan - Pendekatan Alternatif Pendidikan Anak Usia Dini (PAUD). Jakarta: Rineka Cipta

[2] Darmodiharjo D. 1979. Santiaji Pancasila. Surabaya: Usaha Nasional.

[3] Fatimah I. 2012. Pendidikan Moral Anak Melalui Pengajaran Bidang Studi PPKn Dan Pendidikan Agama .Didaktika. Jurnal Ilmiah VOL.XII NO.2, 338-347

[4] Hurlock, B E. 1978. Perkembangan Anak Jilid 2. Erlangga

[5] Jamilah. 2013. Penanaman Nilai-nilai Moralitas Pada Anak Usia Dini (Study Kasus di Panti Balita dan Madania Kids Maguwoharjo Depok Sleman Yogyakarta). Thesis. Perpustakaan UIN Sunan Kalijaga

[6] Kohlberg, L. (1964). Development of Moral Character and Moral Ideology. Dalam William Crain. Theories of Development, Concepts and Applications Third Edition. Prentice Hall. Englewood Cliffs, New Jersey 07632

[7] Lawrence J. Schweinhart, Significant Benefit: The High/Scope Perry Preschool Study through Age 27 (Ypsilante, Mich: High/Scope Press, 1993

[8] Miles M. 1992. Analisis Data Kualitatif. 1. Huberman. Penerjemah: Tjetjep. UI. 1992

[9] Murdiono, M. 2007. Metode Penanaman Nilai Moral Untuk Anak Usia Dini. Jurnal Kependidikan . Lemlit UNY.pdf

[10] PiagetJ. (1932). The Moral Judgment of the Child (M. Gabain, Terj.). New York: Free Press, 1965

[11] Supriyanto, D. 2016. Perkembangan Nilai Agama Dan Moral Anak Dan Pendidikan Keagamaan Orang Tua. E Journal. Kopertis 4.or.id/index.php/madding/article/....1624

[12] Tim Penyusun MKD IAIN Sunan Ampel Surabaya. 2011. Merevitalisasi Pendidikan Pancasila Sebagai Pemandu Reformasi. Surabaya: IAIN Sunan Ampel Press

[13] Martinis, Y dan S. Sabri 2013. Panduan PAUD. Jakarta: Referensi (Gaung Persada Press Group)

[14] Silabus Kelombok B TK PAUD LABSCHOOL Jember Tahun Pelajaran 2016 - 2017 Semester I dan II

[15] Syamsudin Amir. Pengembangan Nilai-nilai agama dan Moral pada Anak Usia Dini. Yogyakarta: Jurnal Pendidikan Anak, volume 1, Edisi 2, Desember 2012. 